\title{
Coastal upwelling along the southwest coast of India - ENSO modulation
}

\author{
K. Muni Krishna \\ Dept. of Meteorology and Oceanography, Andhra University Visakhapatnam - 530 003, India
}

Received: 6 March 2008 - Accepted: 3 June 2008 - Published: 11 June 2008

\begin{abstract}
An index of El Niño Southern Oscillation (ENSO) in the Pacific during pre monsoon season is shown to account for a significant part of the variability of coastal Sea Surface Temperature (SST) anomalies measured a few months later within the wind driven southwest coast of India coastal upwelling region $7^{\circ} \mathrm{N}-14^{\circ} \mathrm{N}$. This teleconnection is thought to result from an atmospheric bridge between the Pacific and north Indian Oceans, leading to warm (cold) ENSO events being associated with relaxation (intensification) of the Indian trade winds and of the wind-induced coastal upwelling. This ENSO related modulation of the wind-driven coastal upwelling appears to contribute to the connection observed at the basin-scale between ENSO and SST in the Arabian Sea. The ability to use this teleconnection to give warning of large changes in the southwest coast of India coastal upwelling few months in advance is successfully tested using data from 1998 and 1999 ENSO events.
\end{abstract}

Keywords. Oceanography: general (Ocean prediction; Upwelling and convergences) - Oceanography: physical (Upper ocean processes)

\section{Introduction}

An atmospheric teleconnection between the Pacific and north Indian Oceans leads to ENSO related fluctuations of the Indian seasonal winds during pre monsoon and summer monsoon (Klein et al., 1999; Webster et al., 1999; Meyers et al., 2007; Huang and Shukla, 2007; Jensen, 2007). This PacificIndian connection is best developed during the early part of the year and leads to a weaker (stronger) Walker circulation over the tropical North Indian Ocean during El Niño (La Niña) events. These seasonal wind fluctuations have a pronounced impact on Sea Surface Temperature (SST) in the broad North Indian Ocean (Webster and Yang, 1992) as

Correspondence to: K. Muni Krishna

(kailasam15@yahoo.co.in) diagnosed from statistical analyses of large-scale, spatially smoothed data sets.

Upwelling involves the offshore transport of surface water and its replacement by cold, nutrient rich subsurface water. The southwest coast of India is a monsoon dominated coast. Coastal upwelling occurs along the coast during the southwest monsoon season (JJAS) between $14^{\circ} \mathrm{N}$ and $7^{\circ} \mathrm{N}$ (Banse, 1959; Darbyshire, 1967; Johannessen et al., 1981; Lathipha and Murthy, 1985; Maheswaran, 2000; Muni Krishna, 2007; Rao et al., 2004; Sharma, 1978). In this region, upwelling is a wind-driven process and the strength of alongshore winds stress modulates the coastal divergence and hence the input of cold upwelled water over the shelf. A strengthening of the alongshore wind stress enhances upwelling and results in lower SST over the shelf. Hence, if ENSO is modulating the Indian trade winds, SST variability in the southwest coast of India upwelling region should be related to the ENSO variability in the Pacific. The intent of this study is to examine the link between ENSO driven wind changes, upwelling and SST along the southwest coast of India.

\section{Data and methodology}

The Multivariate ENSO Index (MEI) is used to monitor the status of ENSO during the season prior to the JuneSeptember upwelling period along the southwest coast of India (see: http://www.cdc.noaa.gov/ kew/MEI). The MEI is a composite index of the six main observed variables over the tropical Pacific. AS the MEI integrates more information than other indices, such as the Southern Oscillation Index (SOI) based on Tahiti-Darwin pressure difference, it is thought to reflect the nature of the coupled ocean-atmosphere system better (Wolter, 1987; Wolter and Timlin, 1993). Significantly positive (negative) values of the MEI indicate El Niño (La Niña) conditions in the Pacific. The April-May MEI time series was chosen in order to correspond to the one

Published by Copernicus Publications on behalf of the European Geosciences Union. 


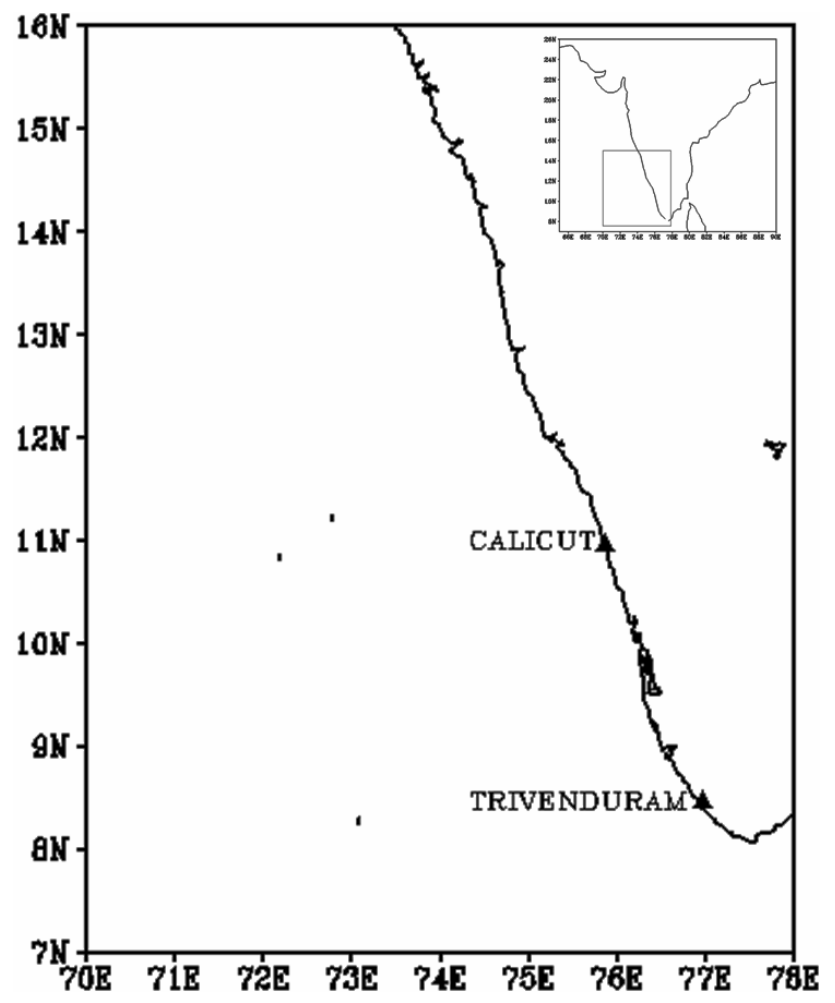

Fig. 1. Map of the Southwest coast of India.

month lag between the Pacific and the Indian observed by the previous studies, but similar results are obtained with the adjacent bi-monthly values.

Rather than using pre-processed or spatially smoothed monthly fields, individual SST and wind observations were extracted from the ICOADS release 1-ab database (Woodruff et al., 1987, 1998; Worley et al., 2005) over the region $14^{\circ} \mathrm{N}$ to $7^{\circ} \mathrm{N}$ along the southwest coast of India (Fig. 1). An updated version of the CODE software (Mendelssohn and Roy, 1996) was used for this purpose. Each box extends one degree in latitude and offshore by 150 to $250 \mathrm{~km}$. The offshore extension has little effect on the data averaged within each box because most of the ICOADS data in that region are concentrated along a narrow track parallel to the coast with data density sharply decreasing on both sides. The ICOADS database release $1-a b$ allows selection of the data following a wide range of criteria such as the platform type, the measurement devices and the origin of the data.

Within each box, seasonal (June-September) time series of Sea Surface Temperature Anomalies (SSTA) and Alongshore Wind Stress Anomalies (AWSA) were derived from the selected individual observations. Monthly SSTA and AWSA are derived from the SST and the alongshore wind stress time-series by removing the monthly seasonal cycle. Monthly anomalies are average from June to September and the resulting time series are standardized using the overall standard deviation. The AWSA time series anomalies are de- trended to remove the artificial trend in reported wind speed from ICOADS (Ward and Hoskins, 1996). Positive values of AWSA and negative values of SSTA respectively indicate stronger than averaged trade winds and enhanced upwelling.

\section{Results}

The correlation between both the seasonally averaged SSTS and AWSA and the April-May MEI of the same year, characterizes the connection between ENSO and southwest coast of India upwelling. Correlation coefficients greater than 0.45 $(p<0.01)$ between MEI and the seasonally averaged SSTA off southwest coast of India indicating that the MEI is a statistically good predictor of the magnitude of coastal temperature anomalies off southwest coast of India between $7^{\circ} \mathrm{N}$ and $14^{\circ} \mathrm{N}$ (Fig. 2). The MEI is also good predictor (through inverse relationship) of the seasonally averaged alongshore wind stress off southwest coast of India between $7^{\circ} \mathrm{N}$ and $14^{\circ} \mathrm{N}$ (Fig. 2).

These two empirical relationships are mutually consistent and support the existence of a linkage, through an atmospheric teleconnection, between ENSO in the Pacific and coastal upwelling off southwest coast of India. They suggest the following scenario: significantly positive (negative) April-May MEI values are indicators of an mature El Niño (La Niña) in the Pacific. The resulting weakening (strengthening) of the southwesterlies in the summer season reduces (enhances) the alongshore upwelling favorable wind component. As a result, the intensity of the wind-induced coastal divergence that brings cold subsurface water over the shelf is reduced (enhanced) during warm (cold) events in the Pacific during southwest monsoon season (Fig. 2). During La Niña events, the reverse occurs. An analysis of monthly SSTA time series indicates that the link between ENSO and the southwesterlies to be statistically significant $(p<0.01)$ in June and is best developed from July-September $(r>0.4)$.

Fisheries off southwest coast of India are regularly affected by environmentally-induced fluctuations in fish abundance and by disruptions of the fish migration patterns (Longhurst and Wooster, 1990). The area between $8^{\circ} \mathrm{N}-$ $10^{\circ} \mathrm{N}$ is one of the major fish spawning grounds off southwest coast of India. It is also a place where the fisheries rely on the exploitation of the seasonal migration of several fish populations that migrate between $14^{\circ} \mathrm{N}$ and $7^{\circ} \mathrm{N}$ (Banse, 1968). Moderate upwelling conditions maximize both spawning success and the seasonal migration flux (Longhurst and Wooster, 1990). In that context, the 1-2 month lag between the development of mature ENSO events in the Pacific and their signature along the southwest coast of India offers an opportunity for early warning of significant change in coastal upwelling and SST which may directly affect fish populations and the fisheries. The recent severe 1997/1998 El Niño and 1998/1999 La Niña events provide ideal conditions for testing such a forecast. Such a 

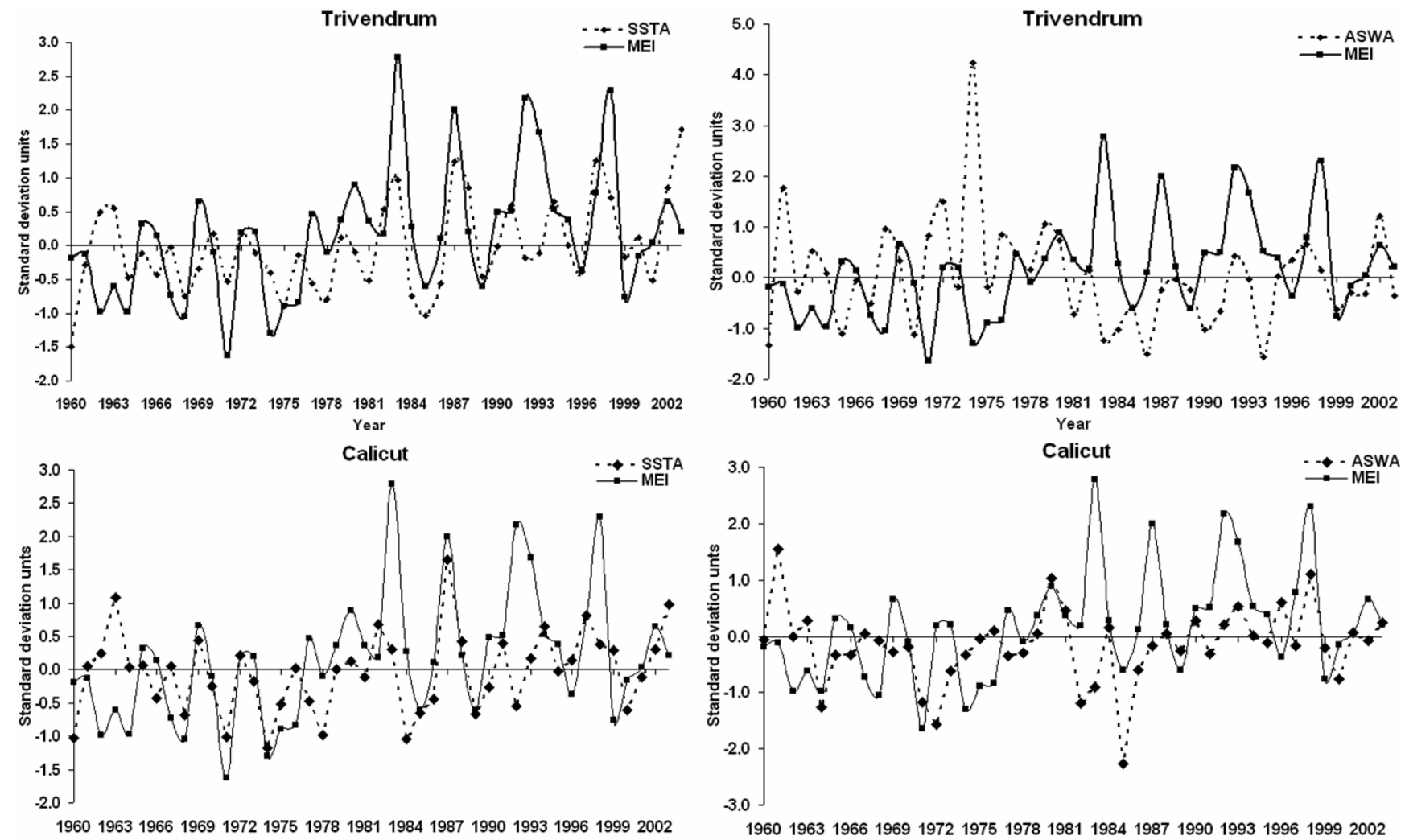

Year

Year

Fig. 2. 1960-2003 standardized time series of SSTA (bold, left panel) and AWSA (bold, right panel) for selected $1^{\circ} \times 1^{\circ}$ located along the southwest coast of India. Superimposed is the time series of the April-May MEI (dot) of the year.

test is performed using the fitted linear relationship between MEI and SSTA from $1960-2003$ for $8^{\circ} \mathrm{N}-10^{\circ} \mathrm{N}$ coastal box and the MEI values in April-May 1997 and 1998 (Fig. 3). The validity model is assessed by comparing the predicted SSTA values for June-September 1998 and 1999, with in situ observations. Following the development of El Niño conditions in the Pacific during 1997, the model forecasts anomalous warm temperatures off southwest coast of India in 1997 (predicted mean June-September SSTA in the $8^{\circ} \mathrm{N}-10^{\circ} \mathrm{N}$ box $=0.2 \pm 0.46^{\circ} \mathrm{C}$ ). Observations within the region have recorded a relaxed upwelling and positive sea surface temperature anomalies (observed mean June-September in the $8^{\circ} \mathrm{N}-10^{\circ} \mathrm{N}$ box $=+0.71^{\circ} \mathrm{C}$ ). Opposite conditions are forecast for 1998 with predicted mean June-September 1998 SSTA of $-0.24 \pm 0.07^{\circ} \mathrm{C}$ ), while observations reported an intensified upwelling and a negative mean June-September 1998 SSTA of $-0.17^{\circ} \mathrm{C}$.

During two successive seasons, the relaxed upwelling of 1998 and the intensified upwelling of 1999, environmental conditions were far from optimal for the fish populations and the fishing industry. The relationship between the MEI and the southwest coast of India upwelling could have provided early warning of the potentially adverse reproductive conditions as well as of the reduced fish migration fluxes. Expert

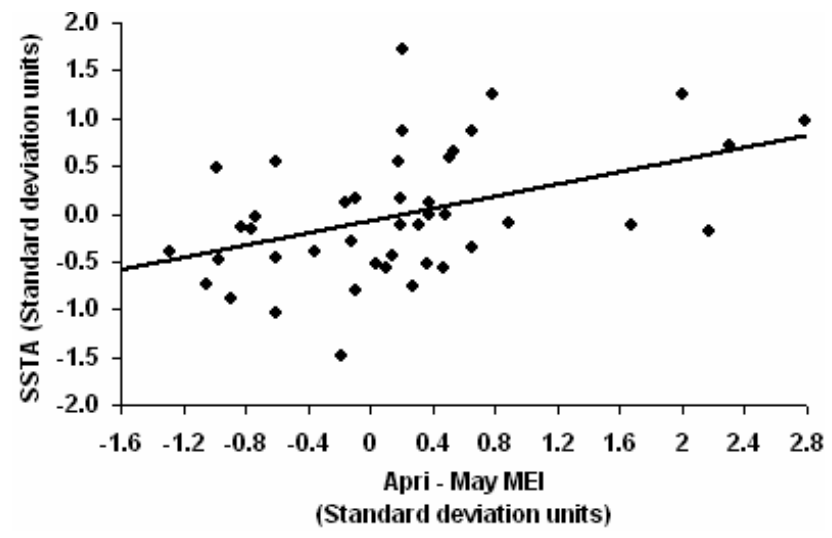

Fig. 3. Scatter plot of June to September averaged SSTA versus the April-May MEI for the Trivendrum, from 1960 to 2003. The equation of the linear regression fitted to the data is SSTA $=0.32 \times$ MEI (with $r^{2}=0.45$ and $p<0.01$ ).

and decision support systems could then have been used to incorporate such environmental information within fisheries management (Korrubel et al., 1998). Such systems can provide invaluable information to both the fishing industry and the institutional bodies in charge of regulating the fisheries. 


\section{Conclusion}

This study has shown that an index of ENSO in the Pacific (the April-May value of the MEI) is able to account for a significant part of the variability of coastal SST anomalies measured a month later within the wind driven coastal upwelling region off southwest coast of India from $7^{\circ} \mathrm{N}$ to $14^{\circ} \mathrm{N}$. This observed pattern of correlation between the ENSO index and the SST anomalies is interpreted as being the result of a teleconnection between the Pacific and the North Indian Ocean. The teleconnection appears to be most developed off Kerala $\left(8^{\circ} \mathrm{N}-10^{\circ} \mathrm{N}\right)$, where a simple linear correlation model between the ENSO index and SST anomalies explains more than $50 \%$ of the regression variance $(r=0.53)$. An atmospheric bridge is thought to be the link between the two distant oceans. Fluctuations in seasonal winds off southwest coast of India are coherent with the fluctuations in the Pacific ENSO index and modulated the intensity of coastal upwelling and the advection of cold water over the continental shelf. In previous studies wind driven coastal upwelling was not considered to be a significant process contributing to the link between conditions in the Pacific and southwest coast of India.

The lag between ENSO in the Pacific and the response of the Arabian Sea can be used to give warnings of large changes in the southwest coast of India upwelling few months in advance. This was successfully tested by using data from the 1998 and 1999 ENSO events. Such warnings of drastic environmental anomalies can help to achieve precautionary management of marine resources by reducing the risk of over-exploitation during period of extreme climate events. This can have significant benefits for countries whose economies have been severely damaged by climatic fluctuations during the last 25 years, and where limited financial resources are directed towards supported resource assessment rather than towards environmental monitoring.

Acknowledgements. I thank Climate Diagnostics Center, NOAA for providing me with the ICOADS data and PFEL people for their fruitful discussions to improve the quality of the manuscript. I am also thankful to the reviewers for their constructive comments.

Topical Editor S. Gulev thanks one anonymous referee for her/his help in evaluating this paper.

\section{References}

Banse, K.: On upwelling and bottom-trawling off the southwest coast of India, J. Mar. Biol. Assoc. India, 1, 33-49, 1959.

Banse, K.: Hydrography of the Arabian Sea shelf of India and Pakistan and effects on dimersal fishes, Deep Sea Res., 15, 45-79, 1968.

Darbyshire, M.: The surface waters off the coast of Kerala, southwest India, Deep Sea Res., 14, 295-320, 1967.

Huang, B. and Shukla, J.: Mechanisms for the Interannual Variability in the Tropical Indian Ocean. Part II: Regional Processes, J. Climate, 17, 2937-2960, 2007.
Jensen, T. G.: Wind-Driven Response of the Northern Indian Ocean to Climate Extremes, J. Climate, 17, 2978-2993, 2007.

Johannessen, O. M., Subbaraju, G., and Blindheim, J.: Seasonal variations of the oceanographic conditions off the southwest coast of India during 1979-1975, Fiskeridirektorates Skrifter, Serie Havundersoekelser, 18, 247-261, 1981.

Korrubel, J. L., Bloomer, S. F., Cochrane, K. L., Hutchings, L., and Field, J. G.: Forecasting in South African pelagic fisheries management: the use of expert and decision systems, South African J. Mar. Sci., 19, 415-424, 1998.

Klein, S. A., Soden, B. J., and Lau, N. C.: Remote sea surface temperature variations during ENSO: evidence for a tropical atmospheric bridge, J. Climate, 12, 917-932, 1999.

Lathipha, P. N. and Murthy, A. V. S.: Studies of Upwelling along the west coast of India using geopotential Anomaly, Ind. J. Mar. Sci., 14, 10-14, 1985.

Longhurst, A. R. and Wooster, W. S.: Abundance of Oil Sardine (Sardinella longiceps) and Upwelling on the Southwest Coast of India, Can. J. Fish. Aquat. Sci., 47, 2407-2419, 1990.

Maheswaran, M.: Upwelling along the southwest coast of India, Ind. J. Mar. Sci., 15, 20-24, 2000.

Meyers, G., McIntosh, P., Pigot, L., and Pook, M.: 17The Years of El Niño, La Niña, and Interactions with the Tropical Indian Ocean, J. Climate, 17, 2872-2880, 2007.

Muni Krishna, K.: A Study of Coastal Upwelling Phenomena along the Indian Coasts Using Satellite Observations and Model Simulations, Visakhapatnam, India: Andhra University, Ph.D thesis, Andhra University, India, 2007.

Rao, A. D., Madhu Joshi, Indu Jain, Mahapatra, D. K., and Babu, S. V.: Modeling of coastal upwelling along the southwest coast of India using POM, Proc. METOC-2004, 183-188, 2004.

Sharma, G. S.: Upwelling off the southwest coast of India, Indian. J. Mar. Sci., 17, 16-20, 1978.

Ward, M. N. and Hoskins, B. J.: Near surface wind over the global ocean 1949-1988, J. Climate, 9, 1877-1895, 1996.

Webster, P. J., Moore, A., Loschnigg, J., and Leban, M.: Coupled Ocean-Atmosphere Response dynamics in the Indian Ocean during 1997-9, Nature, 40, 356-360, 1999.

Webster, P. J. and Yang, S.: Monsoon and ENSO: Selectively Interactive Systems, Q. J. Roy. Meteorol. Soc., 118, 877-926, 1992.

Wolter, K. and Timlin, M. S.: Monitoring ENSO in ICOADS with a seasonally adjusted principle component index, in: Proceedings of the 7th Climate Diagnostics Workshop, Norman, OK, NOAA/N MC/CAC, NSSL, Okalahoma Clim. Survey, CIMMS and the School of Meter. University of Oklahoma, 52-57, 1993.

Woodruff, S. D., Diaz, H. F., Elms, J. D., and Worley, S. J.: COADS released 2 data and metadata enhancement for improvements of marine surface flux fields, Phys. Chem. Earth, 23, 517-526, 1998.

Woodruff, S. D., Slutz, R. L., Jenne, R. L., and Steurer, P. M.: A Comprehensive ocean-atmosphere data-set, B. Am. Meteorol. Soc., 68, 1239-1250, 1987.

Worely, S. J., Woodruff, S. D., Reynolds, R. W., Lubker, S. J., and Lott, N.: ICOADSRelease 2.1 data and products, Int. J. Climatol. (CLIMAR-II Special Issue), 25, 823-842, 2005. 